\title{
A Study of the Feminization of Young Men's Dress in the Upper Class in the Late Qing Dynasty and the Early Republic of China
}

\author{
Tian Zhiwei ${ }^{1} \&$ Liu $\mathrm{Yu}^{1}$ \\ ${ }^{1}$ College of Fashion and Art Design, Dong Hua University, Shanghai, China \\ Correspondence: Liu Yu, College of Fashion and Art Design, Dong Hua University, Shanghai, China. E-mail: \\ liuyu32@dhu.edu.cn
}

Received: August 5, 2021

Accepted: August 15, 2021

Online Published: August 30, 2021

doi:10.5539/ass.v17n9p25

URL: https://doi.org/10.5539/ass.v17n9p25

\begin{abstract}
When the decree to cut pigtails and change clothing was introduced in the late Qing and early Republican periods, there were many clothing changes. The feminization of men's clothing was widely discussed at the time as a distinctive dress code trend. This article looks at the historical documents that documented this event and analyses the specific manifestations of this phenomenon by looking at the groups and regions where the feminization of men's clothing took place. The article analyses the phenomenon of men wearing women's clothing to blur their gender and explore the image of cross-dressing men in the society of the time and its meaning. Through the analysis of historical documents on the diverse, outward expressions of cross-dressing men, the fact that diversity in masculinity existed in that time is illustrated. This leads to further induction of the respective images of masculinity and a discussion of the various reasons behind this phenomenon. The article concludes with an attempt to reveal the motives that produced the feminization of men's dressing, both in terms of external social and internal causes, and to discuss whether the feminization of men's dressing in the late Qing Dynasty involved transgender identity the analysis of masculinity.
\end{abstract}

Keywords: feminization of men's wear, cutting pigtails and changing clothes, male images, cross-dressing phenomenon, masculinities

\section{Introduction}

As the feminization of men's clothing has not received much attention in previous studies on men's dress in the context of braid-cutting, most of the research on braid-cutting has been on the relationship between the act and society public opinion choices concerning braid-cutting. A small number of studies have looked at individual reactions to cutting and dressing. It is noteworthy that most of these studies focus on the situation after the promulgation of the regulations on the cutting of pigtails and the change of clothes, but there is little discussion of how people dressed before the decree, which is why this article explores it here.

After the Sino-Japanese War, there was a trend in Chinese society to cut pigtails, shave hair, and change to Western dress. The revolutionaries propagated the idea of shaving hair and changing to Western dress, which led to a trend that began in 1900 and was most prevalent in academic circles, spreading to all walks of life as a means of fighting the Manchurian revolution. However, as the trend was controversial until it was officially declared a decree, and the Clothing Regulations promulgated in the early years of the Republic of China were not implemented, public opinion was divided on cutting the braids and changing the clothes.

Against this backdrop, there were various attempts and breakthroughs in the way people dressed. The feminization of men's clothing was one of the phenomena that emerged from this, as the process of cutting pigtails and changing clothing was gradually clarified, and the feminization of men's clothing in late Qing and early Republican Chinese society took on a strong political meaning.

\section{Who and Where the Feminization of Men's Clothing Takes Place?}

In the early 20th century, Chinese men were indecisive about the dress as cutting braids and changing clothes had not yet become a universal norm. As a result, there were many problems with the disruption of hairstyles caused by the cutting of pigtails and the gender reversal in dressing caused by the change of clothing. The change in men's style in the late Qing dynasty because of the braid-cutting and clothing change trend was a recurring topic of discussion in the media and press, both in the mainstream and rural opinion. Even in the 
special commemorative issue of Sun Yat-Sen's first term in office, the issue of men's dress and haircut still occupied a considerable amount of space. It is thus clear that, against the ambiguous backdrop of the time, the great deal of work done on men's dress code in the late Qing Dynasty caused quite a stir in the society of the time.

In 1883 Huang Shiquan compiled a book entitled "Song Nan Meng Ying Lu" in which he wrote: "男子装扮娇俏, 像女人的装束(Men dress up as women)."1, and in 1897 the newspaper "News" recorded: "男装偏从女服, 式样 竟无男女之分 (Men's clothes are so much like women's clothes that there is no distinction between men and women)." . There was also the feminization of men who carried small mirrors with them permanently to dress up. There are many records of the alienation of men's dress, with various writers expressing their positions.

On April 26, 1901, in an issue of the newspaper "Tong Wen Xiao Xian Bao," there was a ban on men's bangs in Suzhou at the time: "前苏州府张子虞太守因见吴中风俗浇漓男女装束矫异特命差役将男子留起前刘海者 一并拿办又在中和闻之说书人钱幼郎为差人轧去钱在死求免贿以五元将前刘海薙去闻者快之近来沪上妓 女留置二寸许者恨不得太守治之也(The former governor of Suzhou, Zhang Ziyu, saw that the customs in Wu were different for both men and women, so he ordered his servants to take the men who kept their bangs in front of them and also heard in Zhonghe that the storyteller Qian Young had been sent to the police to roll away the money in order to get rid of the bribe of five yuan to remove the bangs. ${ }^{3 "}$ The story is that in recent times, prostitutes in Shanghai have been wearing two-inch haircuts and that the sheriff has been treating them as such.

Subsequently, on June 6, 1902, the Chinese and foreign recent events section of the Tianjin Da Gong Bao in the fourth page of the Henan region reported such a current event: “近时习俗有头蓄短发梳令下垂者油省纳绔少 年亦染此风锡帅伤人密访闻电报局有数人系此打扮.......(Recently, it has been the custom to have short hair on the head and comb to make it droop, and the fop boys in Bian Province are also dyed in this style. $)^{4 \text { " The }}$ young men in the Kaifeng area were shown with a short hairstyle, and it was found through secret visits that the dress was not uncommon. In the same year, Da Gong Bao, August 31, Tian Jin Shi Shi (Tianjin Current Affairs). In the article, it says: "未出示严禁事照得津郡五方亲处良莠不济每有无赖棍徒头打散辫身穿镶嵌花边簇新 衣衫...... (No strict prohibition is shown for the matter to be illuminated by the good and bad in the five proximity places of the county of Tianjin every time there are scoundrels and rogues with their heads in loose braids wearing inlaid lace and tufted new clothes .......)."

Although the men in the Tianjin area did not have the bangs as previously described but had their hair in loose braids, they were not dressed in the usual men's robes and coats of the late Qing Dynasty but in a garment with flowery border clusters. When talking about the look of the green-skinned hooligans, Shi Bao of June 9, 1906, reported in the Yangzhou area that "......青皮流垊多剪发覆额作刘海装此种恶习万不可长...... (green-skinned hooligans mostly cut their hair over their foreheads for bangs and such vices must not be allowed to grow ). ${ }^{6}$ "Thus, it can be seen that the reason for catching them was the bangs styling such unusual men's hairstyle.

By the early years of the Republic in 1911, this phenomenon was still present. In the Sun Yat-sen special of December 30 of Min Li Bao, a large section on cutting pigtails and changing clothes took up most of the space in the special, and in the column "Southeast and Northwest," it was told that students in Shanghai were cutting pigtails and changing clothes to oppose the pseudo-Manchu regime on the one hand, and that young male students were changing their dress to meet the trends of the times on the other. ${ }^{7}$ As this dressing trend was unique at the time, it was recorded in many newspapers and magazines, and space is limited to collate some of the contents in a table (as shown in Table 1). This shows what kind of men, where and how, pursued this trend of alienation in the late Qing and early Republican periods.

Table 1. Feminization of men's clothing and where it occurs in selected newspapers

\begin{tabular}{llll}
\hline Newspaper Name & Article content & Man identification & Location \\
\hline \multirow{2}{*}{ Da Gong Bao } & $\begin{array}{l}\text { 浮薄少年之额前垂发俗名浏海形同妇女类近娼优 } \\
\text { 不知羞耻实属有伤风化 }\end{array}$ & $\begin{array}{l}\text { Immature young } \\
\text { men }\end{array}$ & Beijing \\
\hline Min Li Bao & $\begin{array}{l}\text { 宁垣自剪发之风气一起侧身军学界者均一唱百和 } \\
\text { 逐次将发剪去者颇不之人...... }\end{array}$ & young men & \multirow{2}{*}{ Nanjing } \\
\hline Da Gong Bao & $\begin{array}{l}\text { 官宦子弟留齐眉穗并于两侧附丝带油光粉亮无异 } \\
\text { 于女子10 }\end{array}$ & The wealthy son & \multirow{2}{*}{ Shandong } \\
\hline
\end{tabular}


学堂风气开而学生装束亦日趋怪异或蓄发齐眉甘 效娼优质丑态或洋装薙辫...... ${ }^{11}$

Shi Bao

杭州人之剪去发辫者不多而剪去者多自成一式发

作人字形从中心披下并无头颖自远望之无异刘海 young men

Students

Suzhou

The above records show that the feminization of men's clothing because of the cutting of pigtails and the change of costume was concentrated in young men. These men were mainly students and sons of wealthy families and disengaged men and idle members of society. It is no coincidence that students, as direct participants in new ideas and reforms, took an active part in a new trend as it emerged. The sons and daughters of officials had much higher exposure to emerging things than the general social class due to their special status. This alienation of the male dress code was practiced as a remarkable experiment, a way of finding pleasure in a time of upheaval. The prominent locations for this phenomenon are large cities or ports of entry, with provincial capitals being the main inland areas. As for ports of entry or cities where there was a lot of student exchange, the impact of cutting the pigtails and changing clothes was more pronounced. However, this masculine dressing occurs without any clear geographical division in both the north and the south.

\section{Concrete Manifestations of the Feminization of Men's Clothing}

Regarding the style of men's cross-dressing from the late Qing Dynasty to the early Republic, these cross-dressing men were bold and innovative in their dressing. From hair and makeup to accessories, the men's love of beauty was different from women's.

\subsection{Hairstyles and Makeup}

The feminization of men produced changes in male appearance, mainly in the form of male hairstyles, of which the length of hair and the appearance of fringes were two critical features. For example, according to an illustration of the change in the front bangs of men in Shanghai that appeared in the 1910 issue of the Shenzhou Daily (Figure 1), the change in men's bangs in the decade from 1900 to 1910 is illustrated from right to left. Furthermore, in 1910, men cut off their long braids to form a center-parted shoulder-length haircut, which, according to Shi Bao in 1911, was very similar to the hairstyle worn by women at the time, and which was more in keeping with the dress of young women, as can be visually explained by the illustration in the following article, “女学校中查出男子骇闻（Boy caught infiltrating girls' school）."

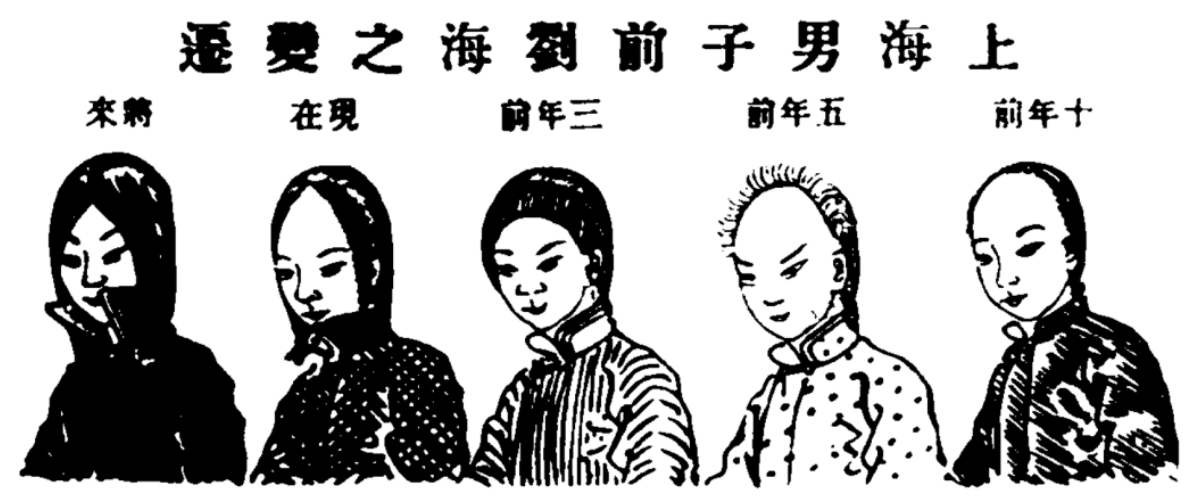

Figure 1. Changes in the front bangs of Shanghai men in the April 1910 issue of Shenzhou Daily

It is important to note that the vision of the future of men's hair in the changes is likely to be speculation based on this new and unique trend in the image of men. Current records of men's hairstyles from 1910 onwards show that cutting the hair and changing the clothes was necessary for men after the enactment of Fu Zhi Tiao Li. Looking at this picture from the present perspective, the future vision is not consistent with historical facts. However, as part of the masculine trend of the time, such hairstyles were likely to have existed in the Republican period. Judging by the group to which the feminization of men's clothing in the previous article corresponds, this behavior was still a small group of men, so it is not entirely unreasonable for the men in the picture to display a feminine temperament.

About the changes in men's hairstyles, apart from the drawing in the Shenzhou Daily, the presentation of men's hairstyles in Shi Bao in the same year is more historically accurate. The latter is more realistic than the former, 
which was ahead of its time and fashionable, in showing how most men's hairstyles changed in this historical context (Figure 2). The fourth man from top to bottom in the picture, as the cutting of the braid and changing to a different costume was still under discussion, the men's hairstyle was not prescribed, and so bangs were used, but they were not herringbone fringes, but more like how the hair would have looked if it had been cut and not known how to manage the natural growth.

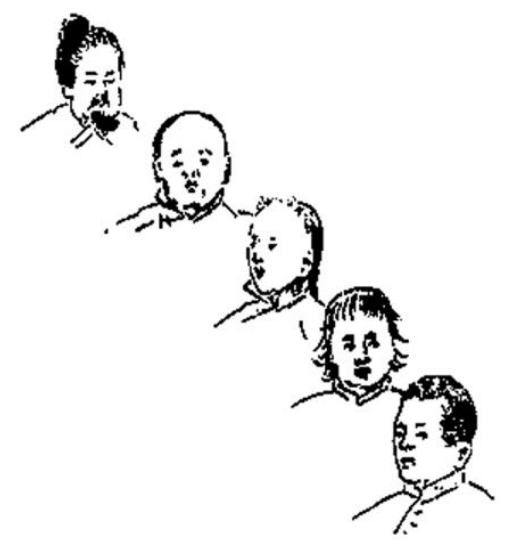

Figure 2. Diagram of changes in men's hairstyles as drawn in Shi Bao of November 13, 1910

In addition to the bangs, another type of hairstyle was to cut the braid and leave the missing hair at the top of the head and tie it in a small bun at the back of the head, as seen in an illustration in Shi Bao in 1913 (shown in Figure 3), where a man was caught by the officers at the time dressed as a woman, which is more like the way a woman would tie her hair.

Regarding men's makeup, according to a quick review of current affairs in Tianjin and Shandong by Da Gong Bao in May 1908, these men, who were fond of dressing up, had a uniform characteristic of make-up-shiny and greasy. In 1919, The News described men's makeup as "面涂脂粉宛似女流(shiny with grease and powder, just like a woman)," and in 小时报 (附録馀興), entitled “男扮女装之妖人 (Men dressed as women)," the makeup was described as. "头上带花面颊敷粉怪像百出(The man with flowers on his head and powder on his cheeks looks like a woman) ${ }^{13}$ ". Men would resort to applying powder to look more like women, to make their skin fair and thus look like a woman. Although it is said that men needed to be made up to look like women, it was also necessary for men to have good faces.

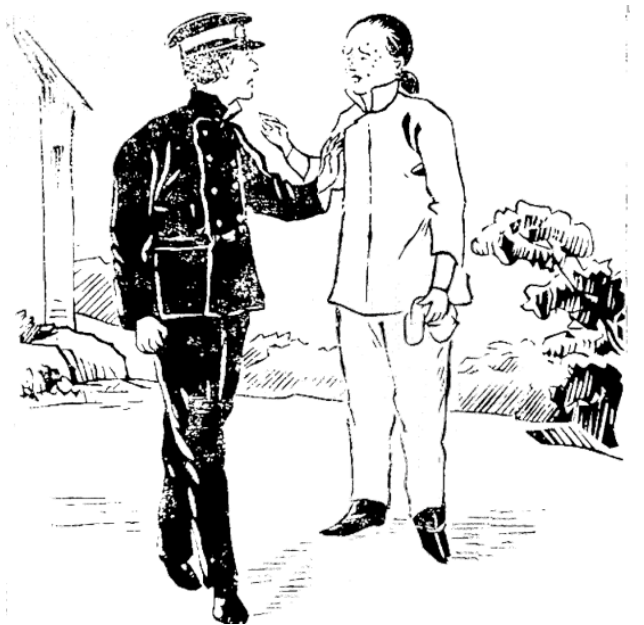

Figure 3. Men dressed as women arrested by the police as drawn in Shi Bao, March 25, 1913

There is an illustration in the Min Li Pictorial from around 1909 (shown in Fig. 4) of a man caught pretending to be a woman, and the description of the scene in the upper left-hand corner shows that the man is referred to as a 'beautiful man.' ${ }^{14}$. On the one hand, this suggests that the man's delicate and beautiful face was the reason why he was not instantly recognizable when pretending to be a woman, and on the other hand, it confirms the question of identity that young men with a good life and a broad outlook were the main perpetrators of the act. After all, if the primary conditions of life were not met, there would be no way to talk about this kind of cross-dressing for men, which requires sophisticated dressing. 


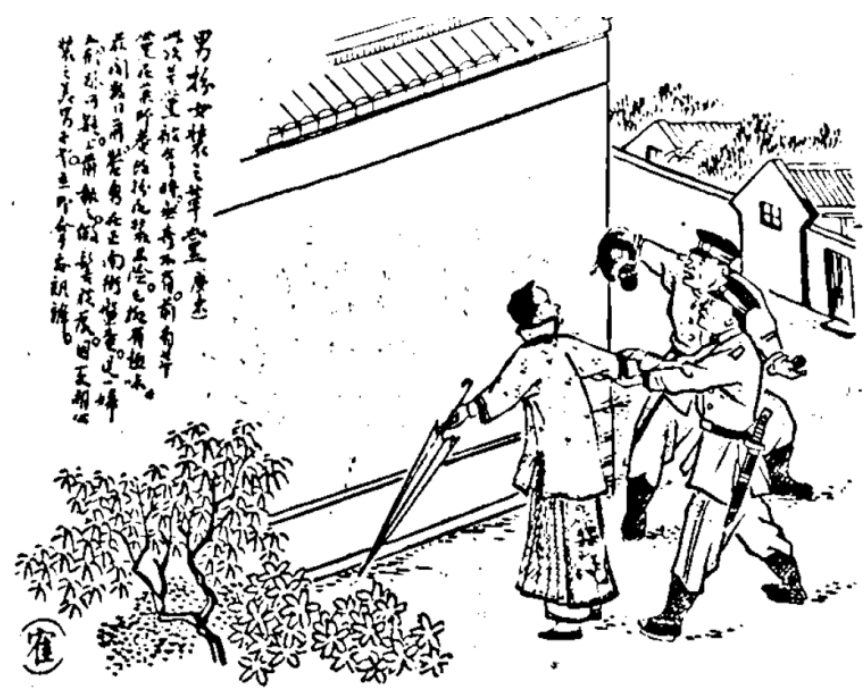

Figure 4. An account of the social story of a man dressed as a woman in the 1909 Min Li Pictorial

\subsection{Dressing and Accessories}

The feminization of men's clothing had no fixed pattern in dress, but basically, what women wore was what men wore. However, there were some cases where men were dressed as men and were identified as women because of their hairstyles, as mentioned above, as reflected in the 1909 issue of Yи Lun Shi Shi Ваo Ти Ниа, "nӥ Хие xiao Zhong cha chu nan zi hai wen (Men Found in Girls' Schools)" shown in Figure 5, which shows that these men dressed very similarly to women, making it easy for them to blend into girls' schools. This was possible, according to the report on this image: "九江福音教向有之同文书院内附设女校一所。肄业者不下数十人。不 料校中竟有男子三人混迹肄业。半年以来西园管理员亦未识破。近日不知如何行迹暴露。经管理员严加 核验果于女生中查出男子三人。 (There is a girls' school attached to the same school as the Jiu Jiang Evangelical Church. No less than a score of students attended the school. It was unexpected that there were three men in the school. For half a year, the caretaker of the West Garden did not detect them. Recently, I do not know how their behaviors were revealed. Finally, the caretaker has been able to identify three men among the girls.)." 15

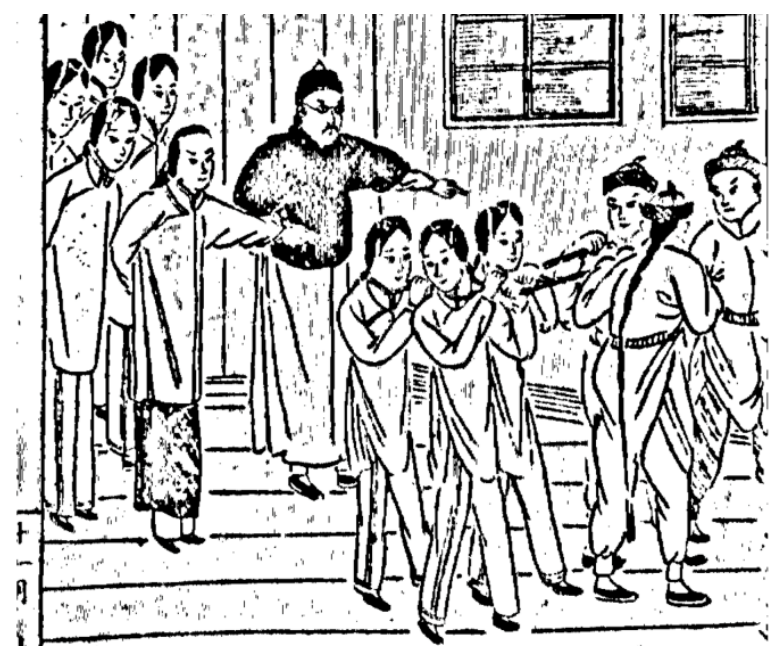

Figure 5. The appalling discovery of men in a girls' school in the Journal of Yu Lun Shi Shi Bao Tu Hua, Vol. 11, No. 13, 1909

The three men in chains in this picture look essentially the same as the female students in the upper left-hand corner, which is how they managed to blend into the girls' school undetected for so long. The men and women are all dressed in the same way: the typical top and trousers of Han Chinese women in the late Qing dynasty, with the tops reaching below the hips, standing collars and sloping lapels, rounded hems, and an overall tailored look of a young woman. In addition to this, the man in Figure 4 above is wearing a woman's pointy footwear with a top and skirt, and the skirt is pleated. This is an example of how men's clothing was feminized by wearing women's clothing directly, replicating all the external features of a woman. 
In other cases, however, some of the good-looking teenagers do not wear women's clothes outright but rather create a feminine image through their own already sophisticated dressing and fringes, much like the dandy boy who was a sharp dresser, self-obsessed and identified with women in the West at the time. This group of people was likely the dandy boys and rich kids, who were modifying for the sake of fashion and fun. According to the illustration in the 1908 edition of the journal Shi Shi Bao Tu Za Zu (Fig. 6), the young man in this picture is dressed in a different style from the relatively subdued and plain robes worn by men, with floral and bamboo decorations, and long braided fringes that look like those of women but follow the overall pattern of men's clothing.

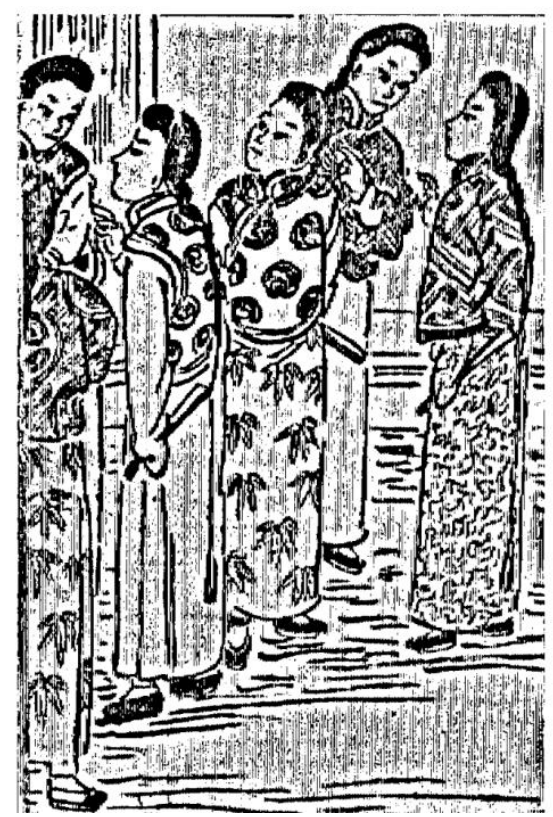

Figure 6. Illustration from Shi Shi Bao Tu Za Zu 1908 No. 264, Teenagers gathered in front of the notice

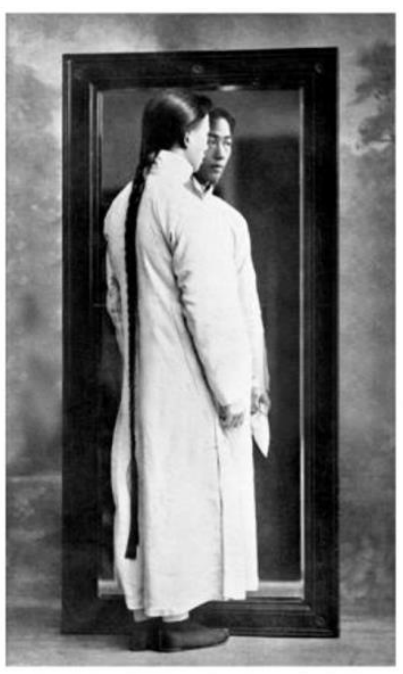

A CANTONESE BEFore THE REVOLUTION OF 1911.

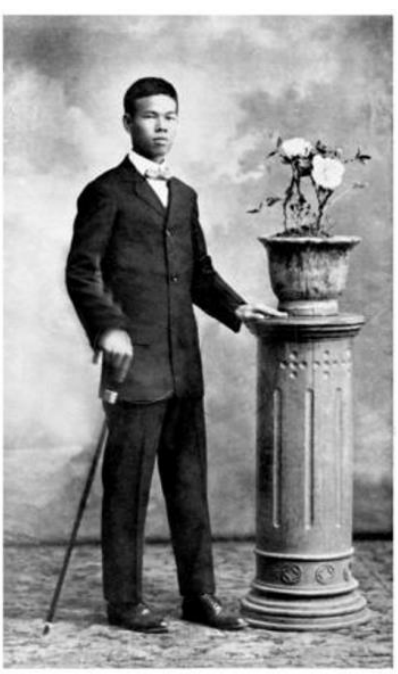

A CANTONESE After the REvolution of 1911.

Figure 7. Photograph from a King's Yorkshire postcard, c. 1908, showing men dressed around 1911

The feminization of men's dressing also comes from details such as the inlaid lace clusters on their clothing and the ribbons tied around the sides of their hair ...... Xin Wen Bao at the time records that “额扎粉红绸巾垂落肩 后, 足踏花鞋。(The forehead is tied with a pink silk scarf draped behind the shoulders, and the feet are treading on flowery shoes)." There is also a record of the famous literary figure and revolutionary Liu Yazi, who was invited to be the secretary of the Provisional President's Office in Nanjing, wearing a large red cloak with his hair draped over his shoulders in front and back. ${ }^{16}$. This shows that men adopted these very feminine elements of dress, such as pink, big red, and silk ribbons, to enhance their feminine features to look more like women. 
The reason why men look so much like women is not just the result of hair, makeup, or clothing alone, but the combination of elements that make up a man's female appearance, as shown on a postcard of the King of Yorkshire circa 1908 in Figure 7. The man's ankle-length robe on the left of the picture is clearly distinguished by the fact that the braid, although not cut, and the long hair grown on top of the head and pinned behind the ears, is indistinguishable from a woman's long braid and is no longer typical of Qing dynasty men's hairstyles. Furthermore, with the handkerchief in his hand and the pointed shoes on his feet, the whole look vividly demonstrates the feminine state of the man. This contrasts with the man on the right, who has changed to western clothing by cutting his hair, and the two produce a very different image of manhood.

\subsection{Physical Characteristics}

In addition to women's "clothes" and "makeup," the body, as the carrier of these clothes, can deepen the impression of men dressed up as femininity brought by appearance. It has been explained in the previous article that most of these cross-dressers are beautiful teenagers from wealthy families. When women dress up, the characteristics of men that are not obvious in teenagers are significantly weakened to have the cognition of male and female. Braid-cutting and easy to obey the law does not discipline men's bodies. At this level, their bodies are very complimentary, with the help of inherent physical advantages to achieve the expression of female characteristics cannot be in harmony. Just imagine, adult men's bodies with prominent male gender characteristics, such as Adam's apple, beard, developed muscles, and other prominent male characteristics, are less comfortable when carrying feminine dress.

The feminization of men's wear is due to the direct involvement of women's dressing up and the practical expression of the "beautiful young" male group. Because of its dress-up behavior and female characteristics, under the joint action of the two, it became a unique existence in the swing period before the promulgation of the law of easy to wear braid and became a fashion trend.

\section{Possible Reasons for the Feminization of Men's Wear}

From the late Qing Dynasty to the early period of the Republic of China, the phenomenon of cross-dressing in the process of role transformation of social and historical development, for different purposes, also presented different reasons. There is the influence from the social environment, but also the role of the individual itself.

\subsection{Social Factors}

After the Sino-Japanese War of 1894-1895, China set off a wave of study abroad upsurge in the international environment. During the late Qing Dynasty to the Republic of China, tens of thousands of people went to Japan to study. In such a fluid process, the phenomenon of cross-dressing appeared in Japan is very likely to be seen by Chinese men at that time through such communication. It has been made clear that cross-dressing men are from affluent families and are more likely to be exposed to the phenomenon or to have more access to the anecdotes of cross-dressing abroad. For them, feminizing men's wear may be about copying and having fun with it.

Cross-dressing and culture in modern Japan mention that in the late Meiji period (about 1900-1912), some handsome young men in Japan won people's favor by dressing as women or dressing like prostitutes. "Smoothies" dandified themselves in silk kimonos and white socks to win the favor of women." 17 Smoothies is a term used to describe young men in Tohoku who look very much like girls. In addition, Morinaga, a famous Japanese novelist, wrote in his novel Vita Sexualis that two completely different kinds of manliness appeared in schools in the late Meiji period: "Roughneck" and the other is the aforementioned "Smoothies." (Roughneck refers to a man's character, which is rough and brave through blushing and thick neck. Furthermore, Smoothies is a man who has smooth skin and describes men who have trouble distinguishing between the sexes.) They use their clothes to express their sexual orientation and gender identity. ${ }^{18}$

The pursuit of an androgynous appearance by men was a similar phenomenon in Japan and other Western countries. Djurdja Bartlett, Senior Research Fellow at the London College of Fashion, University of the Arts London Socialist Dandies international: East Europe, 1946-59, makes the point that "the various extremely ornate images of masculinity that emerged in Western society at the beginning of the twentieth century The image of the dandy, in the context of Western society, is that what these men do is a historical inheritance, something that really happened in their history. But when such cross-dressing occurs in socialist countries or in societies that have never historically allowed it, the act is a symbol of danger and is a great challenge to some inherent authority." 19

The study abroad movement was an excellent catalyst for the development of the democratic revolutionary movement in China at the time, and Chinese people on exchanges abroad passed on information about foreign countries to China through various channels, and the sons of China's wealthy gentry were aware of such matters. 
Moreover, foreign behavior likely provided a reference for Chinese cross-dressing boys, leading them to want to imitate the costumes of prostitutes, or to express their sexuality through cross-dressing to please others, or even aspire to be part of the revolution. The combination of these reasons led to the feminization of male clothing to oppose the regime of the time.

Back in China, according to the activities of Tong meng Hui in Hong Kong and Macao and the recollections of women's circles in Guangdong who participated in the revolution recorded in Experiences of the Revolution of 1911: Witnesses' Telling's, we can see that: "As for most people, they mistakenly think that to cut braids is to wear foreign clothes. Therefore, those who do not want to or cannot afford to wear foreign clothes still have concerns about cutting braids." ${ }^{20}$ People do not have an accurate understanding of braid-cutting comfortable clothing. The same is true for these teenagers, who were not fully aware of the significance of men dressing up as women and making a fuss about their hair, perhaps even for themselves, as they unwittingly challenged the controversial braids' political significance at the time.

\subsection{Individual Factors}

In the late Qing Dynasty and the early Republic of China, social media's comments and attitudes on the feminization of men's clothing determined the emergence of this phenomenon, rather than leaving it at the beginning. The individual's attitude towards public opinion is one of the reasons for the emergence of the cross-dressing phenomenon. Recorded by the Chinese newspapers and magazines in the part of the original recorded for newspapers and magazines (Table 2), for the men dress alienates the attitude of this phenomenon are apparent into three categories.

Table 2. A record of attitudes towards men's cross-dressing in significant newspapers

\begin{tabular}{|c|c|}
\hline Newspaper & The original \\
\hline \multirow{3}{*}{ Shi Bao } & 1906 年 6 月 9 日： ......前发覆额......拿获此等装束之恶少数名 ...... \\
\hline & $\begin{array}{c}1908 \text { 年 } 4 \text { 月 } 16 \text { 日: ....... (笑) 少年好以短发覆额此轻佻装束未曾禁绝......重申薙发之令 } \\
\text { 而定义极严之刑可行否? }\end{array}$ \\
\hline & 1910 年 10 月 3 日： ......时髦少年常有敷油于发者...... \\
\hline Xin Wen Bao & 1912 年 4 月 21 日：男扮女装之人妖：少男扮作女子被拘留问题之讨论 \\
\hline Da Gong Bao & $\begin{array}{c}1903 \text { 年 } 3 \text { 月 } 15 \text { 日: ......顽固者多疑恶之心, 若易西装庶改良其脑筋, 而共图文明之进 } \\
\text { 步...... }\end{array}$ \\
\hline Shen Bao & 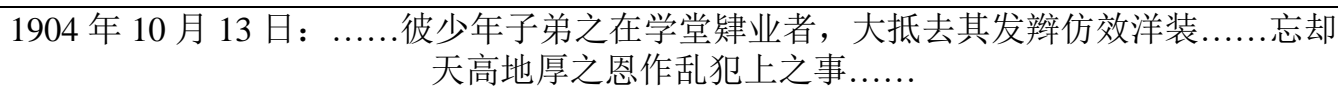 \\
\hline
\end{tabular}

Newspaper reports of different attitudes at different periods show that public opinion includes conservative opposition, open progressives, and relatively neutral expression. The phenomenon of public opinion for men wears feminine or more liberal, otherwise would not be in the early after the ban, also appeared closer to the Republic of China, such "chic teenager." However, it is also possible that the dude is to challenge authority, see the man was punished for dress up after decided to "sort" thrill-seekers.

Different regions and different publications held different attitudes towards the feminization of men's clothing. In addition to the Times mentioned above, Shanghai's Shen Bao, Tianjin's Da Gong Bao, and even Xin Wen Bao, which reported important political news, all expressed their attitudes towards the discussion of braid changing and the resulting changes in men's dressing. Whether it is in the "declaration" to cut braided easy take the concerns of the juvenile behavior attitude, or positive response in Da Gong Bao cut braided clothing and produce a positive response to the call of even jokingly. The public opinion environment reflects that the degree of freedom of social media in the late Qing Dynasty and the early Republic of China is very high.

As a political initiative, both the men involved and the newspapers as a voice should have avoided being involved in political events. Moreover, in the society of the time, the cutting of pigtails and clothing was not yet explicitly legal. The relatively liberal environment allowed these men to dress in women's clothing and create a trend. Regardless of whether it was in line with public perception, it was not easy to do so in the circumstances.

Among the individual factors, fashionable motivation is that which is caused by the need for beauty. The internal demand drive drives people to engage in fashionable activities and move towards fashion, where the person's aesthetic needs are one of the essential conditions that drive fashionable motivation. Because they see others in heterosexual attire and think that it reflects beauty, these teenagers follow suit and dress up as women to satisfy the psychological need to be fashionable. This motivation to dress fashionably had a knock-on effect and was 
reflected in the lower and middle classes from the top down. The wealthy families and student groups led the way before the socially desirable young ruffians, and fops followed suit, which was a process of the lower classes using clothing as a medium to gain identity through imitation, which is explained from the perspective of the aesthetic motivation for the feminization of men's clothing.

From the point of view of the social psychology of clothing, this is very much in line with the theory of freedom to wear clothing. When faced with issues concerning appearance management, the individual is free to decide whether to conform to norms or deviate from them. The degree to which individuals are free to choose their clothing is more clearly influenced by the psychosocial aspect of the freedom to choose their appearance and dress in such a way as to assign themselves to specific cultural categories and groups. ${ }^{21}$ The alienation of men's dress results from the inability to precisely assign themselves to a particular group, which is why such a distinctive image has emerged. The introduction of the braid-cutting and clothing change reinforced the perceived negative image of men's hairstyles at the time. The propaganda of the revolutionaries in the late Qing and early Republican periods likely inspired these male groups to adopt a modified attitude and anti-Manchu sentiments. At the same time, these 'fashion trendsetters' did not want to join the revolutionaries in cutting their braids and changing their clothing to a more Westernized style. They, therefore, chose to respond to the as-yet-unspecified reform measures in a manner that was both male and female. Therefore, the feminization of men's dress was a combination of political opinion and psychological factors that contributed to the dress code of the times.

\section{Masculinity in the Phenomenon of Men's Cross-Dressing}

The division of gender in the above example, according to the sex roles proposed in gender role theory as male and female, is created through clothing as a differentiator in society. According to the socially constructed norms of gender roles, dressing is not an essential need for our bodies. Clothing in the late Qing and early Ming dynasties has always revolved around gender roles and was repeatedly defining the boundaries of gender roles. Specific clothing symbolized different gender identities, and once that setting was recognized, specific clothing referred to a specific gender in society. The reality of men dressing no differently to women is documented in the press, and there are established gender identities for male and female clothing that are only indistinguishable when people see men in women's clothing. The general public's perception of the gender of clothing operates in this way, with members of society being able to communicate their gender identity to each other through the gender represented by their clothing, and clothing becomes a visual representation of gender identity when the characteristics of biological sexes cannot be directly distinguished between men and women. By wearing clothing with clear gender identity and dressing in a feminine manner, men acquire a female gender identity.

The cross-dressing of men in the late Qing Dynasty and the early Republic of China, because of the cutting of pigtails and the change of clothing, rejected the original paradigm of gender roles and proved the possession of heterosexual qualities by wearing female clothing, thus negating the gender role code and the construction of clothing gender roles in which men displayed femininity through cross-dressing. As the composition of the wearer is complex and diverse when cross-dressing occurs, the originally established social judgment of gender through clothing appears to be non-unique, thus giving rise to the characterization of men who are biologically male, but through dressing up assume a female gender role. This suggests that in addition to the commonly perceived dominant masculinity, males with feminine characteristics are also included in the gender role construct. Thus, diversity in masculinity produces and shapes the result of physiological men but whose external expression is ultimately not uniquely expressed.

The single stereotype of masculinity did not tolerate the image of masculinity produced by this act of male cross-dressing, and at the same time, the masculinity contained within it was rejected. In terms of binary gender norms, cross-dressing reflected the fact that the only perception of gender in dress was that of male and female and that the gender reflected in dress was the biological gender, resulting in the widespread prohibition and arrest of men who cross-dressed. In addition, the appearance of femininity on the bodies of otherwise dominant masculinity was a great challenge to the semi-colonial and semi-feudal society that had always maintained a gender binary.

The phenomenon of men cross-dressing explains two issues about masculinity. Firstly, masculinity in gender role theory is, in fact, dominant masculinity. When dominant masculinity was challenged by the image of masculinity presented by cross-dressing men, social agents suppressed it. This proves that the social perception of gender at the time was binary, i.e., there was only femininity and masculinity, and in this case, dominant masculinity. Secondly, the phenomenon of cross-dressing illustrates the plurality of the existence of masculinity. Since there was a different type of masculinity than the dominant masculinity, there were different types of cross-dressing 
for men, reflecting different masculinities, which at the same time indicates the diversity of masculinities.

In cross-dressing, more emphasis is placed on the beauty that men themselves possess and the beauty that they are seeking in women. Cross-dressing is, therefore, a quest for aesthetics. They believed that women's dressing suited their aesthetic experience. However, because the state of society at the time could not appreciate the beauty of men's cross-dressing, it categorized this male dressing as an infringement of masculinity, suppressing them as an alternative and even discriminating against them, and the press at the time referred to these cross-dressers by the term 'sirens.'

Because of the dominant social acceptance of dominant masculinity, cross-dressing was discouraged in various ways. The cross-dressing of men as women challenged the dominant masculine group, which was already a deficient status in society at the time. The men's cross-dressing as women was not a concern for the status of the men themselves, and the result was that the dominant masculine group was still forbidden to see any other masculinity.

According to the attribution of the men's cross-dressing group in the late Qing and early Ming dynasties, it was the wealthy gentry or fop boys who produced such feminine behavior. The attribution of this group can be clearly understood based on the cases cited in the previous section and those listed in Table 1. Thus, from the perspective of the diversity theory of masculinity, the young and beautiful men involved in cross-dressing, without discussing their sexual orientation and other motivations, are, if there are, very masculine men. Nevertheless, on the other hand, there are very feminine men, and the different ways in which femininity is expressed are reflected in the men's masculinity. ${ }^{22}$

In his 1989 article 'The birth of the queen,' American gender studies scholar Randolph Trumbach points out that for feminine masculinity in the 18th century, there were roughly four categories: fop, dandy, beau, and molly, with the molly category of masculinity having replaced the former at that time The molly category had by then replaced the first three. ${ }^{23}$. In this way, the masculinity of men who simply dressed themselves to seek the beauty of the opposite sex was highly like that of the dandy; similarly, the masculinity of men who pretended to be prostitutes and dressed as women were highly similar to that of the molly.

The creation of the feminization of men's clothing in the late Qing and the early Republic of China was resisted to varying degrees as it threatened the groups represented by the social hegemony. This suggests that the perception of gender role binary theory was very firmly constructed at the time and subscribed to a single division of gender role theory. When different masculinities emerged, society ignored them as feedback and insisted on dominant masculinity as the only type of masculinity. However, the plurality of masculinities that emerge from the masculine role creates various images of masculinity. Whether it is the 'molly boy' who is attracted to men with hegemonic masculinity, thus aligning the gender binary, the 'dandy boy' who is obsessed with the self, identifies with women, abandons criticism of hegemonic masculinity, and even engages in challenging behavior towards society, or even something in between. "Or the 'dandy boy' who is obsessed with himself, identifies with women, renounces critical hegemonic masculinity and even engages in socially challenging behavior, or even the in-between male, who achieves a figurative expression of plural masculinity.

The causes of male cross-dressing and, ultimately, the presentation of diverse masculinities is due to two broad factors. Externally, the influx of male cross-dressing in the international community gave young men a new perception that men could possess heterosexual qualities, which they were curious to pursue as a form of fun. In the country, due to social unrest, on the one hand, men did not know how to cope with the modifications on the eve of cutting their braids and changing their clothes, so they dressed casually; on the other hand, they knew that cross-dressing was a provocation and did it deliberately. On the other hand, they know that cross-dressing is a form of provocation, so they do it intentionally. Part of the reason for this is because of their own psychological and physical needs, so they cross-dress to satisfy themselves, and part of the reason is simply aesthetic because they recognize the beauty of women. Men, as social subjects, chose to dress in women's clothing, in an era when women were not of high status, they saw the charm of women and were willing to present their aesthetic through their female identity, and what they did was equally ahead of their time as the gesture shown by cross-dressing.

Under the stereotype of binary perceptions of gender roles, it is natural to generalize cross-dressing men as women. By looking at the concept of masculinity and its related concepts in this phenomenon, the issue of transgender identity with men wearing women's clothing is discussed in terms of the purpose and perception of cross-dressing in the context of multiple masculinities. The "dandy boy" group of men who dress up in women's clothing but are more interested in changing their appearance do not cross-dress in a transgender way. The "molly boy" and "prostitute boy" groups, however, are those who aim to admire men who are obsessed with dominant masculinity. They are more concerned with the physical and psychological expression of femininity, 
and cross-dressing is simply a way to amplify this, and this cross-dressing is a form of transgender expression. Thus, on the one hand, men cross-dressing illustrates people's daring behavior and perceptions in the late Qing and the early Republic of China. However, on the other hand, cross-dressing was not entirely transgender but more a manifestation of the diversity of masculinity and a focus on masculinity itself.

\section{Conclusion}

Cut braided in clothing, under the influence of Qing dynasty's feminine because of its subordinate to the group and the tremendous social background, to let the drag in this period become a reality. By unconventional dress image, to meet the specific needs of the psychological and physical, to the different dressed.

In terms of the genesis of the feminization of men's clothing, the political direction led to cross-dressing behavior. In the lead-up to the late Qing and early Ming dynasties, the feminization of male clothing when the braid-cutting and cross-dressing ordinance was in force carried a clear political bias, and the transformation of men's braids was provocative in the anti-Qing process. The participants in the feminization of men's clothing young men and students - were the mainstay of the later revolution, although they did not explicitly state that the act aimed to challenge the old system. In the social context of the time, however, the act did have this connotation. On a cultural level, the feminization of men's clothing was due to a combination of aesthetics and identity. As a new style of dress in the domestic social context of the time, there was a tendency for people to be attracted to it and to turn up their noses at it. One part of the male population implied an aesthetic difference, creating a motivation to pursue female fashion. Others, unaware of what they were doing, imitated them at random to gain an identity in a time of turmoil. Of course, some do it just for the fun of it. At the same time, the influx of the feminization of men's clothing from abroad led to creating a new masculine image. In their quest to have fun with this new trend abroad, they recreated the scene by imitating it. In this way, the feminization of men's clothing also provides evidence of the existence of diversity in masculinity.

The presence of the men's wear feminine shows the expression of masculinity in men or more open and accessible. Even if the public opinion towards the phenomenon of uneven, part of the male or bold to try this unique fashion. Although this behavior is advanced, society is not due to its remarkable be stop completely. It was not until the New Deal came into power that all kinds of laws were tightened that the feminization of men's wear gradually disappeared from public view.

\section{References}

Altenburger, R. (2005). Is It Clothes that Make the Man? Cross-Dressing, Gender, and Sex in Pre-Twentieth-Century. Asian Folklore Studies, 64(2), 165-205. Retrieved from https://www.jstor.org/stable/30030419

Bartlett, D. (2013). Socialist Dandies international: East Europe, 1946-59. Fashion Theory, 17(3), 249-298. https://doi.org/10.2752/175174113X13597248661701

Bian, X. Y. (2014). Zhong Guo Jin Xian Dai Hai Pai Fu Zhuang Shi. Shanghai: Donghua University Press.

Bright, R. K. (2017). Migration, Masculinity, and Mastering the "Queue": A Case of Chinese Scalping. Journal of World History, University of Hawaii Press, 26(3/4), 551-586. Retrieved from https://www.jstor.org/stable/26537622

Chang, S. Y. (2009). The Pigtail-Cutting Turmoil and the Related Social Attitudes in Early Twentieth-century China. Journal of the Museum of Chinese History, 22(12), 1-56. https://doi.org/10.7058/TAHJ.200912.0001

Chou, H. L. (1997). Striking Their Poses: The History of Cross-Dressing on the Chinese Stage. TDR, The MIT Press, 41(6), 130-152. Retrieved from https://www.jstor.org/stable/1146629

Connell, R. W. (2009). Gender, Men, and Masculinities, Quality of human resources: gender and indigenous people. Eolss Publisher.

Cornell, R. W. (2003). Masculinity. Beijing: Social Sciences Academic Press.

Fan, Y. (1988). The Fall of the Masculine: The Vicissitudes of Chinese Masculinity with Jiao Baoyu as a Case Study. Beijing: The International Culture Publishing Company.

Fang, G. (2007). A qualitative study on the construction of masculinity in male sex workers. Beijing: Renmin University of China.

Fang, G. (2007). Diversity Analysis of Masculinity Practice. Jinan Journal (Philosophy and Social Sciences Edition), 29(6), 51-56. https://doi.org/10.3969/j.issn.1000-5072.2007.06.009

Gao, R., \& Zhang, J. Q. (2015). Study of Cross-Dressing Phenomenon and Gender Consciousness from the Late 
Qing Dynasty to the Period of the Republic of China. Journal of Zhejiang Sci-Tech University, 34(2), $24-28$. https://doi.org/10.3969/j.issn.1673-3851.2015.01.006

Gao, X. M. (2017). A Study on the Expectation of Gender Role in European and American Dress Culture. Nanjing: Southeast University Press.

Ge, Y. X. (1989). Hu You Za Ji Song Nan Meng Ying Lu Hu You Meng Ying. Shanghai: Shanghai Ancient Books Publishing House.

Hennen, P. (2008). Faeries, Bears, and Leathermen: Men in Community Queering the Masculine. University of Chicago Press.

Liu, Y. (2011). Zhong Guo qi pao wen Hua shi (The Cultural History of Chinese Qipao). Shanghai: History of Shanghai People's Fine Arts Publishing.

Ma, Y. X. (2002). Cross-dressing and culture in modern Japan. Japan studies review, 6, 21-43. Retrieved from https://asian.fiu.edu/projects-and-grants/japan-studies-review/journal-archive/volume-vi-2002/yuxin-crossdressing.pdf

Ōgai, Goldstein, S., \& Ninomiya (Translator). (1909). Vita Sexualis. Tuttle Publishing.

Sun, S. (2015). A Practical Study of Sexual Genus from the Perspective of Subject Construction Taking Men with Cross-Gender Temperament as the Research Object. Heilongjiang: Heilongjiang Academy of Social Sciences.

Trumbach, R. (1991). Sex, Gender, and Sexual Identity in Modern Culture. Journal of the History of Sexuality, 2(2), 168-203. Retrieved from https://www.jstor.org/stable/3704033

Wu, S. Z., \& Huang, R. (2002). Qian Lun Xin Hai Ge Ming Qian Xi Kuang Biao Tu Qi De Jian Bian Yun Dong. Journal of Yangzhou University (Humanities and Social Sciences Edition), (2), 9-13. https://doi.org/10.3969/j.issn.1007-7030.2002.02.002

Zhang, D. A. (2006). Political Struggle over Body: Changing of Hairstyle in Modern China. Chinese Social History Review, (1), 265-290. Retrieved from https://www.sinoss.net/qikan/uploadfile/2010/1130/6234.pdf

Zhang, J. Q. (2009). Cong Yi Yuan Dao Er Yuan: Jin Dai Zhong Guo Fu Zhuang de Chuan cheng jing mai. Beijing: China Textile Press.

Zhao, L. C. (2012). Experiencing the Revolution of 1911: Witnesses Telling's (Vol. 1: The Activities of the Tongmenghui in Hong Kong and Macao and the Memories of Guangdong Women's Participation in the Revolution). Beijing: China Literature and History Press.

Zhou, H. C., \& Fang, G. (2015). Study on Masculinity among men with gender-awareness. Chinese Journal of Sexual Science, 24(11), 111-115. https://doi.org/10.3969/j.issn.1672-1993.2015.11.039

\section{Notes}

${ }^{1}$ Ge Yuanxi: 沪游杂记·淞南梦影录·沪游梦影, “刺花短袜窄鞋帮, 裤脚重重黑锻镶。装束双跌娇俏甚, 行 来绝似女儿妆。” It is written: "The socks are short and narrow, and the trousers are heavily wrought in black. The outfit was so delicate that she walked like a daughter." Shanghai: Shanghai Ancient Books Publishing House, 1989, p.132.

${ }^{2}$ Xin Wen Bao published an article on July 10, 1897, entitled "Zai Lun Nan Nü Fu Shi Zhi Wang (Re-discussing the delusion of men's and women's clothing)," in which it was written that "今人之自鄙人男装偏从女服、衣缘 尚饰之离奇......其式竟无男女之分..... (today's people since the despised men's clothing from the women's clothing, the edge of the clothing still decorated the bizarre ...... its style is not even the difference between men and women .......)".

3 From the April 26, 1901 issue of the Tong Wen Xiao Xian Bao, a ban on bangs refers to men's cross-dressing and fringes.

4 The discovery of the fop's bangs through secret visits was mentioned in the Da Gong Bao of June 6, 1902.

5 In the Da Gong Bao of August 31, 1902, it was said that scoundrels in the Tianjin area wore fancy clothes and broke their braids, and this phenomenon was published in the current affairs record of that day.

6 Miscellaneous contents of Shi Bao of June 9, 1906, "Zhuo na qian Liu hai (Arresting the man with bangs)" 
Yangzhou report.

7 On December 30, 1911, the column "Southeast and Northwest" in the Min Li Bao wrote about young students cutting their pigtails and changing their clothes: “沪上学生剪发后必欲易服以炫耀后辈当此军饷贵乏不肯移 助军饷吾不解。(Shanghai students cutting their hair will want to change their clothes in order to show off their descendants when this military scarcity refuses to move to help the military pay I do not understand. ) "

${ }^{8}$ A review of the Beijing area's floating teenage cross-dressers in the Da Gong Bao of July 15, 1908.

9 The Min Li Bao of December 31, 1910, described the haircutting in the academic circles of the Nanjing area (Ning yuan) as a phenomenon of self-pity.

${ }^{10}$ On May 30, 1908, Da Gong Bao published the following article: “绅衿官幕之纨绔子弟, 皆于聚辫外留齐眉 穗, 刷得亮光, 男女无别, 腼不知耻。(The fops of the government officials' curtain are all leaving their eyebrow spikes outside their braids and brushing them to make them shiny, and there is no distinction between men and women, and they are shameless.)." The content of this article is to judge the female dressing of the official fops as a shameless act.

${ }^{11}$ Shi Bao, February 24, 1908, about Suzhou students dressing like prostitutes and their attitudes.

${ }^{12}$ Shi Bao of April 20, 1911, considered young men's fringes to look like women's hairstyles.

13 On April 3, 1919, 小时报 (附録馀興) published an article titled "nan ban nü Zhuang Zhi Yao ren(A man dressed as a woman)," which reported on the appearance of a man dressed as a woman: "A man dressed as a woman with flowers on his head and powder on his cheeks is outrageous.

${ }^{14}$ In 1909 (approx.) the Min Li Pictorial, an account of the social story of men dressed as women (Figure 4) the relevant chart note reads, “男扮女装之革党, ......假发脱落, 身着女装之美男子, 立即擒拿交公办。A beautiful man dressed as a woman is caught with his wig falling off and is then arrested and handed over to the police."

15 A pictorial report on the detection of men in girls' schools in the Journal of Yu Lun Shi Shi Bao Tu Hua, Vol. 11, No. 13, 1909.

${ }^{16}$ Zhang Zhuangnian and Zhang Yingzhen, The Story of Chinese Celebrity Nicknames, Jinan: Shandong Pictorial Press, 2012, p. 243.

${ }^{17}$ Ma Yunxin, Cross-dressing and culture in modern Japan, Japan studies review, Vol.6, 2002, P26.

${ }^{18}$ Ōgai Mori, Sanford Goldstein, Kazuji Ninomiya (Translator), Vita Sexualis, Tuttle Publishing, 1909, P21. “"Roughnecks' refers to Meiji schoolboys from Kyushu who chose male-male sexual practices. 'Smoothies' refers to those boys from northeast, who chose male-female sexual practices."

${ }^{19}$ Djurdja Bartlett, Socialist Dandies international: East Europe, 1946-59, Fashion Theory, 2013, Vol.17, issue 3, P258.

${ }^{20}$ Zhao Liancheng, Experiencing the Revolution of 1911: Witnesses' Telling's, Vol.1, The Activities of the Tong meng hui in Hong Kong and Macao and the Memories of Guangdong Women's Participation in the Revolution, Beijing: China Literature and History Publishing House, 2012, p66.

${ }^{21}$ Kaiser, Li Hongwei Trans. The Social Psychology of Clothing, Volume 2, Beijing: China Textile Press, 2002, pp. 583.

${ }^{22}$ Gao Xiuming, A Study on the Expectation of Gender Roles in European and American Dress Culture, Nanjing: Southeast University Press, May 2017, p23.

${ }^{23}$ Peter Hennen: Faeries, Bears, and Leathermen: Men in Community Queering the Masculine, University of Chicago Press; 2008.7, pp.46. "By the dawn of the eighteenth century in England, the fop, the dandy, and the beau were already coming to be replaced by the "molly," an effeminate male presumed to be interested exclusively in other (masculine) men."

\section{Copyrights}

Copyright for this article is retained by the author(s), with first publication rights granted to the journal.

This is an open-access article distributed under the terms and conditions of the Creative Commons Attribution license (http://creativecommons.org/licenses/by/4.0/). 